\title{
Analysis of Cesarean Section Rate using Robson's Ten Group Classification System and comparing the Trend at a Tertiary Hospital for 2 Years
}

\author{
${ }^{1} \mathrm{RC}$ Prameela, ${ }^{2}$ Gatta Shilpa, ${ }^{3} \mathrm{Asma}$ Farha, ${ }^{4} \mathrm{~S}$ Prajwal
}

\begin{abstract}
Aims and objectives: To classify the cesarean section (CS) in different groups of Robson's ten-group classification system (TGCS) and comparing the rate and relative size of groups with that of previous year at the tertiary hospital.

Materials and methods: This retrospective study was conducted in Cheluvamba Hospital, which is a tertiary hospital attached to Mysore Medical College \& Research Institute, Mysuru, between January 1, 2014 and December 31, 2014. The data collected was compared with the previous year data between January 1, 2013 and December 31, 2013. The data collected included parity, mode of previous delivery, gestational age, onset of labor-spontaneous or induced, delivery notes of labor ward, and operative notes of CS. This data was then applied to the Robson's TGCS for the year 2014 and compared with that of 2013.
\end{abstract}

Results: The total deliveries during 2014 were 12,930 and in 2013 were 15,182. The number of CSs during 2014 was 3,793 and in 2013 it was 3,917. Cesarean section rate in 2014 was $29.33 \%$ while in 2013 it was $25.8 \%$.

The CS rate has come down to half in group I (nulliparous, single, cephalic $\geq 37$ weeks, in spontaneous labor) and to onefourth in group III [multiparous (excluding previous CS) single, cephalic $\geq 37$ weeks, in spontaneous labor] in 2014 .

Conclusion: Robson's TGCS is easy to classify.

Clinical significance: The study showed reduction in CS rate by half in group I and by one-third in group III in 2014 in our institution. This was probably due to the increased awareness among the staff of the institute by the previous year study about higher CS rate.

Keywords: Cesarean section, Classification, Robson's TGCS.

How to cite this article: Prameela RC, Shilpa G, Farha A, Prajwal S. Analysis of Cesarean Section Rate using Robson's Ten Group Classification System and comparing the Trend at a Tertiary Hospital for 2 Years. J South Asian Feder Obst Gynae 2016;8(3):175-180.

${ }^{1}$ Associate Professor, ${ }^{2,3}$ Postgraduate Student, ${ }^{4}$ Junior Doctor

${ }^{1-3}$ Department of Obstetrics and Gynecology, Mysore Medical College \& Research Institute, Mysuru, Karnataka, India

${ }^{4}$ Shyamanur Shivashankarappa Institute of Medical Science \& Reasearch Institute, Davanagere, Karnataka, India

Corresponding Author: RC Prameela, 4544, 16th Main Vijayanagara 2nd Stage, Mysuru, Karnataka, India, e-mail: rcprameela@yahoo.com
Source of support: Nil

Conflict of interest: None

Date of received: 13 April 2016

Date of acceptance: 7 May 2016

Date of publication: July 2016

\section{INTRODUCTION}

Cesarean section (CS) rate is increasing worldwide. Better understanding of CS rates, their consequences, and benefits will improve care and enable learning between delivery units nationally and internationally. There is no justification for any region to have a CS rate higher than 10 to $15 \% .{ }^{1}$ Despite the lack of scientific evidence indicating any substantial maternal and perinatal benefits from increasing CS rates, some studies show that higher rates could be linked to negative consequences in maternal and child health. ${ }^{2-4}$ Increase in CS rate particularly in middleand high-income countries is a major and controversial public health concern. ${ }^{5,6}$

The lack of a standardized internationally accepted classification system to monitor and compare CS rates in a consistent and action-oriented manner is one of the factors preventing a better understanding of this trend and underlying causes. ${ }^{7}$ In 2011, a systematic review and critical appraisal of available classifications for CS concluded that women-based classifications in general and Robson's ten-group classification system (TGCS) in particular, would be in the best position to fulfill current international and local needs. ${ }^{8}$

Robson's TGCS is a woman-based classification. It is conceptually easy, and has clearly defined categories that are totally inclusive, mutually exclusive; there is little room for misunderstanding or misclassification. All information is easily available from medical records. It is easy to implement in both high and low-resource settings. Prospective classification allows for changes in clinical management. ${ }^{7}$ However, it does not specify reason for CS. Strategies to reduce the frequency of the procedure should include avoidance of medically unnecessary primary CS. 
We wanted to classify CS in our referral hospital for 1-year period and also wanted to know the impact on CS rate in different groups due to awareness of our staff after previous year's classification.

\section{MATERIALS AND METHODS}

This is a retrospective study done at Cheluvamba Hospital, Mysore Medical College \& Research Institute at Mysuru. Data was collected from hospital records. It included all women who delivered from January 1, 2014 to December 31, 2014 and compared with the records collected from the previous year, i.e., January 1, 2013 to December 31, 2013 by the same author. ${ }^{9}$ Details about the delivery are taken from the labor ward records and operative notes from the operation theatres. Details like age, gestational age, parity, onset of labor, spontaneous or induced, previous delivery details were taken into consideration, and then classified according to Robson's TGCS for the year 2014.

\section{RESULTS}

The total number of deliveries during the study period was 12,930. Cesarean sections were 3,793. These women were categorized according to Robson's TGCS and were analyzed as per Table 1 .

\section{DISCUSSION}

Groups were interpreted according to M. Robson's et al/ Best Practice \& Research Clinical Obstetrics and Gynaecology. ${ }^{10}$ All groups were analyzed clinically according to Current Progress in Obstetrics \& Gynecology by John Studd. ${ }^{10}$ In our study in 2014, all numerators and denominators in Table 1 added to total numerator and denominator. In group IX, the CS rate is $100 \%$, indicating good data collection. These two factors imply the validity of our study.

The results are also compared with the records of the previous year of the same institute as shown in Table 2.

\section{Cesarean Section Rate}

Cesarean section rate in this study for 2014 was $29.33 \%$. It was higher than the stipulated WHO criteria of $15 \%$. In the year 2013, the CS rate was $25.83 \%$. The CS rate has increased in the year 2014.

The major contribution has been in group V (previous CS, single, cephalic, $\geq 37$ weeks) with $11.12 \%$ and in group II (nulliparous, single, cephalic, $\geq 37$ weeks induced or CS before labor) $10.13 \%$ of the total $29.33 \%$ as shown in Graph 1. In 2013, the highest rate was contributed by group $\mathrm{V}$ where it was $8.45 \%$, and by group I (nulliparous, single, cephalic, $\geq 37$ weeks, in spontaneous labor) was $5.05 \%$.

\section{Clinical Analysis of Each Group}

Group I: It is the most important group of the entire obstetric population. It is one of the groups that not only vary most in the methods of management, but also in terms of outcome, especially the CS rate. The relative size of this group is $27.47 \%$ in 2014, while it is 39\% in 2013. There is decrease in the size of this group in 2014.

Table 1: Classification of CS according to Robson's TGCS in 2014

\begin{tabular}{|c|c|c|c|c|c|}
\hline \multicolumn{2}{|c|}{ Groups } & \multirow{2}{*}{$\begin{array}{l}\text { Number of CS over } \\
\text { total number of } \\
\text { women in each group } \\
218 / 3552\end{array}$} & \multirow{2}{*}{$\begin{array}{l}\text { Relative size } \\
\text { of groups (\%) } \\
27.47 \\
3552 / 12930\end{array}$} & \multirow{2}{*}{$\begin{array}{l}\text { CS rate in each } \\
\text { group (\%) } \\
6.13 \\
218 / 3552\end{array}$} & \multirow{2}{*}{$\begin{array}{l}\text { Contribution made } \\
\text { by each group to the } \\
\text { overall CS rate (\%) } \\
1.68 \\
218 / 12930\end{array}$} \\
\hline 1 & $\begin{array}{l}\text { Nulliparous, single, cephalic, } \geq 37 \text { weeks, in } \\
\text { spontaneous labor }\end{array}$ & & & & \\
\hline 2 & $\begin{array}{l}\text { Nulliparous, single, cephalic, } \geq 37 \text { weeks induced } \\
\text { or CS before labor }\end{array}$ & $1310 / 2654$ & $\begin{array}{l}20.52 \\
2654 / 12930\end{array}$ & $\begin{array}{l}49.35 \\
1310 / 2654\end{array}$ & $\begin{array}{l}10.13 \\
1310 / 12930\end{array}$ \\
\hline 3 & $\begin{array}{l}\text { Multiparous (excluding previous CS), single, } \\
\text { cephalic, } \geq 37 \text { weeks, in spontaneous labor }\end{array}$ & $112 / 2851$ & $\begin{array}{l}22.04 \\
2851 / 12930\end{array}$ & $\begin{array}{l}3.92 \\
112 / 2851\end{array}$ & $\begin{array}{l}0.86 \\
112 / 12930\end{array}$ \\
\hline 4 & $\begin{array}{l}\text { Multiparous (excluding previous CS), single, } \\
\text { cephalic, } \geq 37 \text { weeks induced or CS before labor }\end{array}$ & $168 / 719$ & $\begin{array}{l}5.56 \\
719 / 12930\end{array}$ & $\begin{array}{l}23.36 \\
168 / 719\end{array}$ & $\begin{array}{l}1.29 \\
168 / 12930\end{array}$ \\
\hline 5 & Previous CS, single, cephalic, $\geq 37$ weeks & $1438 / 1484$ & $\begin{array}{l}11.47 \\
1484 / 12930\end{array}$ & $\begin{array}{l}96.9 \\
1438 / 1484\end{array}$ & $\begin{array}{l}11.12 \\
1438 / 12930\end{array}$ \\
\hline 6 & All nulliparous breeches & $214 / 278$ & $\begin{array}{l}2.15 \\
278 / 12930\end{array}$ & $\begin{array}{l}98.16 \\
214 / 278\end{array}$ & $\begin{array}{l}1.65 \\
214 / 12930\end{array}$ \\
\hline 7 & All multiparous breeches (including previous CS) & $90 / 171$ & $\begin{array}{l}1.32 \\
171 / 12930\end{array}$ & $\begin{array}{l}52.63 \\
90 / 171\end{array}$ & $\begin{array}{l}0.69 \\
90 / 12930\end{array}$ \\
\hline 8 & All multiple pregnancies (including previous CS) & $58 / 110$ & $\begin{array}{l}0.85 \\
110 / 12930\end{array}$ & $\begin{array}{l}52.72 \\
58 / 110\end{array}$ & $\begin{array}{l}0.44 \\
58 / 12930\end{array}$ \\
\hline 9 & All abnormal lies (including previous CS) & $69 / 69$ & $\begin{array}{l}0.53 \\
69 / 12930\end{array}$ & $\begin{array}{l}100 \\
69 / 69\end{array}$ & $\begin{array}{l}1.81 \\
69 / 12930\end{array}$ \\
\hline 10 & $\begin{array}{l}\text { All single, cephalic, < } 36 \text { weeks (including } \\
\text { previous CS) }\end{array}$ & $116 / 1042$ & $\begin{array}{l}8.05 \\
1042 / 12930\end{array}$ & $\begin{array}{l}11.13 \\
116 / 1042\end{array}$ & $\begin{array}{l}0.89 \\
116 / 12930\end{array}$ \\
\hline
\end{tabular}


Table 2: Comparison of Robson's TGCS of CSs in 2013 and 2014

\begin{tabular}{|c|c|c|c|c|c|c|}
\hline \multicolumn{3}{|c|}{ Groups } & \multirow{2}{*}{$\begin{array}{l}\text { Number of CS } \\
\text { over total number } \\
\text { of women in } \\
\text { each group } \\
218 / 3552\end{array}$} & \multirow{2}{*}{$\begin{array}{l}\begin{array}{l}\text { Relative size of } \\
\text { groups (\%) }\end{array} \\
27.47 \\
3552 / 12930\end{array}$} & \multirow{2}{*}{$\begin{array}{l}\text { CS rate in each } \\
\text { group (\%) } \\
6.13 \\
218 / 3552\end{array}$} & \multirow{2}{*}{$\begin{array}{l}\text { Contribution made } \\
\text { by each group to the } \\
\text { overall CS rate (\%) } \\
1.68 \\
218 / 12930\end{array}$} \\
\hline 1 & $\begin{array}{l}\text { Nulliparous, single, cephalic, } \\
\geq 37 \text { weeks, in spontaneous labor }\end{array}$ & 2014 & & & & \\
\hline & & 2013 & $766 / 5924$ & $\begin{array}{l}39 \\
5924 / 15182\end{array}$ & $\begin{array}{l}12.95 \\
766 / 5924\end{array}$ & $\begin{array}{l}5.05 \\
766 / 15182\end{array}$ \\
\hline \multirow[t]{2}{*}{2} & $\begin{array}{l}\text { Nulliparous, single, cephalic, } \geq 37 \text { weeks } \\
\text { induced or CS before labour }\end{array}$ & 2014 & $1310 / 2654$ & $\begin{array}{l}20.52 \\
2654 / 12930\end{array}$ & $\begin{array}{l}49.35 \\
1310 / 2654\end{array}$ & $\begin{array}{l}10.13 \\
1310 / 12930\end{array}$ \\
\hline & & 2013 & $679 / 2237$ & $\begin{array}{l}14.73 \\
2237 / 15182\end{array}$ & $\begin{array}{l}30.35 \\
679 / 2237\end{array}$ & $\begin{array}{l}4.47 \\
679 / 15182\end{array}$ \\
\hline \multirow[t]{2}{*}{3} & $\begin{array}{l}\text { Multiparous (excluding previous CS) } \\
\text { single, cephalic, } \geq 37 \text { weeks, in }\end{array}$ & 2014 & $112 / 2851$ & $\begin{array}{l}22.04 \\
2851 / 12930\end{array}$ & $\begin{array}{l}3.92 \\
112 / 2851\end{array}$ & $\begin{array}{l}0.86 \\
112 / 12930\end{array}$ \\
\hline & spontaneous labor & 2013 & $487 / 3750$ & $\begin{array}{l}24.70 \\
3750 / 15182\end{array}$ & $\begin{array}{l}12.99 \\
679 / 2237\end{array}$ & $\begin{array}{l}3.20 \\
487 / 15182\end{array}$ \\
\hline \multirow[t]{2}{*}{4} & $\begin{array}{l}\text { Multiparous (excluding previous CS), } \\
\text { single, cephalic, } \geq 37 \text { weeks induced }\end{array}$ & 2014 & $168 / 719$ & $\begin{array}{l}5.56 \\
719 / 12930\end{array}$ & $\begin{array}{l}23.36 \\
168 / 719\end{array}$ & $\begin{array}{l}1.29 \\
168 / 12930\end{array}$ \\
\hline & or CS before labor & 2013 & $345 / 892$ & $\begin{array}{l}5.8 \\
892 / 15182\end{array}$ & $\begin{array}{l}38.68 \\
345 / 892\end{array}$ & $\begin{array}{l}2.27 \\
345 / 15182\end{array}$ \\
\hline \multirow[t]{2}{*}{5} & $\begin{array}{l}\text { Previous CS, single, cephalic, } \\
\geq 37 \text { weeks }\end{array}$ & 2014 & $1438 / 1484$ & $\begin{array}{l}11.47 \\
1484 / 12930\end{array}$ & $\begin{array}{l}96.9 \\
1438 / 1484\end{array}$ & $\begin{array}{l}11.12 \\
1438 / 12930\end{array}$ \\
\hline & & 2013 & $1287 / 1321$ & $\begin{array}{l}8.7 \\
1321 / 15182\end{array}$ & $\begin{array}{l}97.43 \\
1287 / 1321\end{array}$ & $\begin{array}{l}8.48 \\
1287 / 15182\end{array}$ \\
\hline \multirow[t]{2}{*}{6} & All nulliparous breeches & 2014 & $214 / 278$ & $\begin{array}{l}2.15 \\
278 / 12930\end{array}$ & $\begin{array}{l}98.16 \\
214 / 278\end{array}$ & $\begin{array}{l}1.65 \\
214 / 12930\end{array}$ \\
\hline & & 2013 & $160 / 221$ & $\begin{array}{l}14.56 \\
221 / 15182\end{array}$ & $\begin{array}{l}72.40 \\
160 / 221\end{array}$ & $\begin{array}{l}1.05 \\
160 / 15182\end{array}$ \\
\hline \multirow[t]{2}{*}{7} & $\begin{array}{l}\text { All multiparous breeches (including } \\
\text { previous CS) }\end{array}$ & 2014 & $90 / 171$ & $\begin{array}{l}1.32 \\
171 / 12930\end{array}$ & $\begin{array}{l}52.63 \\
90 / 171\end{array}$ & $\begin{array}{l}0.69 \\
90 / 12930\end{array}$ \\
\hline & & 2013 & $90 / 178$ & $\begin{array}{l}1.17 \\
178 / 15182\end{array}$ & $\begin{array}{l}50.56 \\
90 / 178\end{array}$ & $\begin{array}{l}0.59 \\
90 / 15182\end{array}$ \\
\hline \multirow[t]{2}{*}{8} & $\begin{array}{l}\text { All multiple pregnancies (including } \\
\text { previous CS) }\end{array}$ & 2014 & $58 / 110$ & $\begin{array}{l}0.85 \\
110 / 12930\end{array}$ & $\begin{array}{l}52.72 \\
58 / 110\end{array}$ & $\begin{array}{l}0.44 \\
58 / 12930\end{array}$ \\
\hline & & 2013 & $19 / 81$ & $\begin{array}{l}0.53 \\
81 / 15182\end{array}$ & $\begin{array}{l}23.45 \\
19 / 81\end{array}$ & $\begin{array}{l}0.12 \\
19 / 15182\end{array}$ \\
\hline \multirow[t]{2}{*}{9} & $\begin{array}{l}\text { All abnormal lies (including } \\
\text { previous CS) }\end{array}$ & 2014 & $69 / 69$ & $\begin{array}{l}0.53 \\
69 / 12930\end{array}$ & $\begin{array}{l}100 \\
69 / 69\end{array}$ & $\begin{array}{l}1.81 \\
69 / 12930\end{array}$ \\
\hline & & 2013 & $34 / 34$ & $\begin{array}{l}0.22 \\
34 / 15182\end{array}$ & $\begin{array}{l}100 \\
34 / 34\end{array}$ & $\begin{array}{l}0.22 \\
34 / 15182\end{array}$ \\
\hline \multirow[t]{2}{*}{10} & $\begin{array}{l}\text { All single, cephalic, }<36 \text { weeks } \\
\text { (including previous CS) }\end{array}$ & 2014 & $116 / 1042$ & $\begin{array}{l}8.05 \\
1042 / 12930\end{array}$ & $\begin{array}{l}11.13 \\
116 / 1042\end{array}$ & $\begin{array}{l}0.89 \\
116 / 12930\end{array}$ \\
\hline & & 2013 & $50 / 544$ & $\begin{array}{l}3.58 \\
544 / 15182\end{array}$ & $\begin{array}{l}9.19 \\
50 / 544\end{array}$ & $\begin{array}{l}0.33 \\
50 / 15182\end{array}$ \\
\hline
\end{tabular}

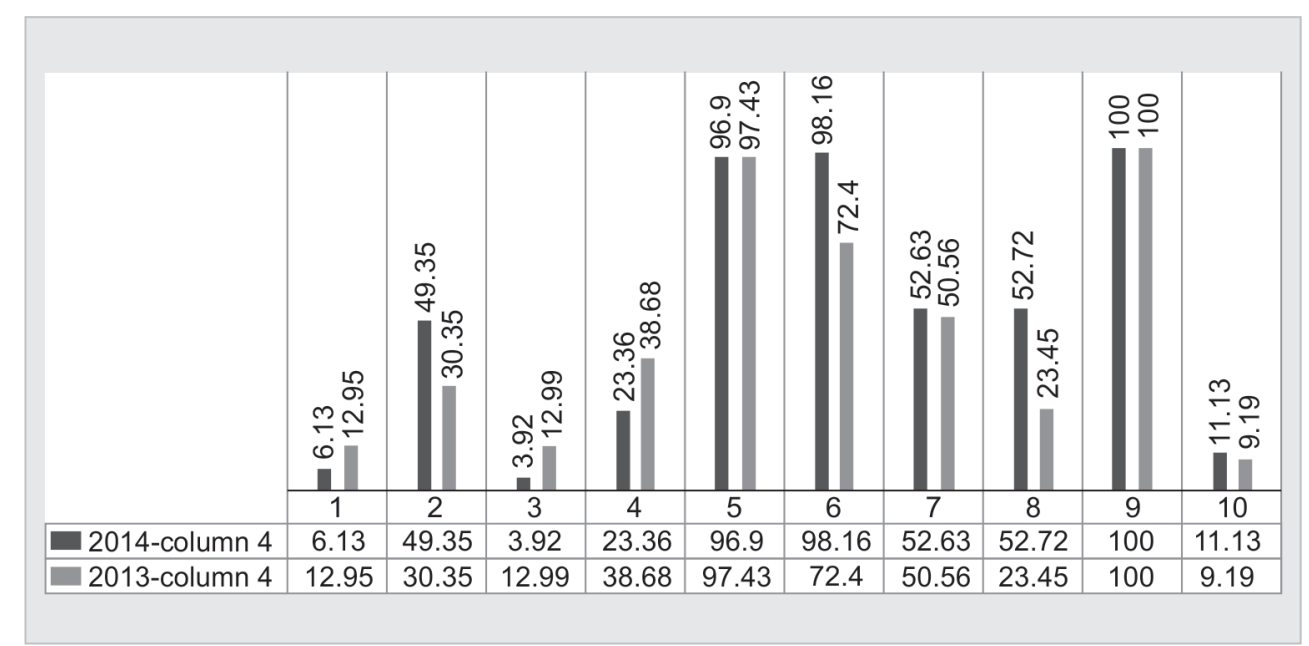

Graph 1: Lower segment cesarean sections rate in each group - column 4 


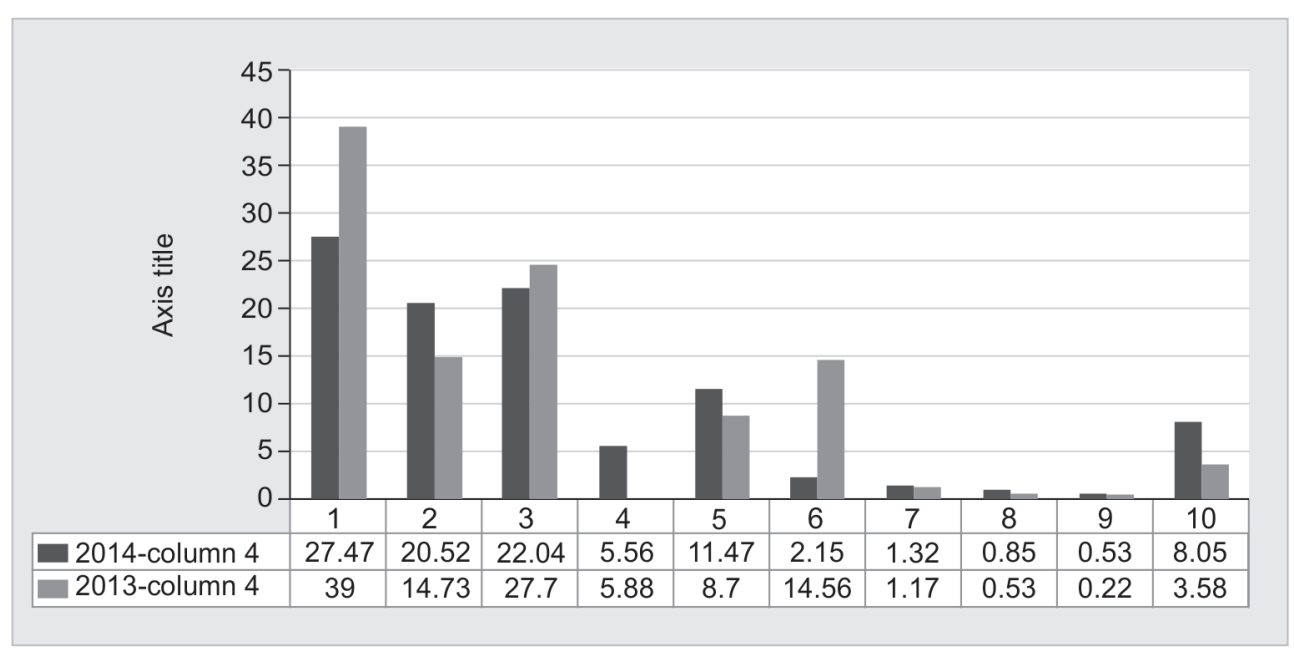

Graph 2: Relative size of the group - column 3

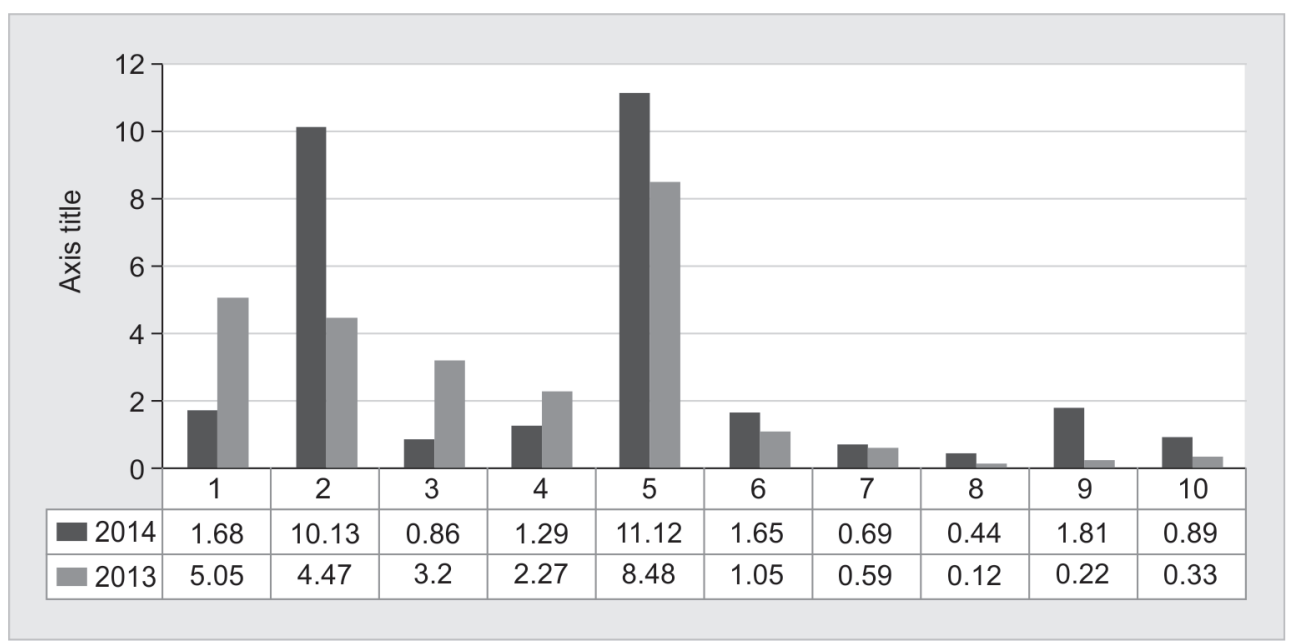

Graph 3: Contribution made by each group to overall CS rate - column 5

The CS rate in this group was $6.13 \%$, and it was $12.95 \%$ in 2013. There was 50\% reduction in CS rate in this group in the study period. We subclassified them to analyze the significant reduction of CS rate in this group.

In 2014, the total number of women was 3,552. Women who underwent CS were 218. Among them, 106 women had previous abortions accounting for $48.62 \%, 54$ had cephalo pelvic disproportion accounting for $24.77 \%$, and the remaining had fetal distress accounting for $26.60 \%$.

It is necessary to manage labor efficiently to reduce the CS rate in this group. Achieving a good uterine contraction, proper usage of oxytocin, diagnosis, and treatment of dystocia by the use of partogram, fetal monitoring in labor helped in reducing the CS rate in this group during the study period.

Group II: The relative size of this group is $20.52 \%$ in 2014 , while it is $14.73 \%$ in 2013 . In 2014, the relative size of this group has increased as shown in Graph 2. The CS rate increased in this group to 20.52 from $14.73 \%$ of the previous year contributing to $10.13 \%$ of the total CSs.
Groups I and II should be analyzed together as well as individually. The larger the relative size of groups II to I, the higher the CS rate will be in groups I and II together. Groups I and II together become the driving force for the increasing primary CS rate. Though it was less in group I in our study, still, because of the increased rate in group II, the contribution of group I+ II is $55.3 \%$. In a similar study done by RC Prameela et al in 2013, the contribution of groups I and II is $53.73 \%$.

Group III: The CS rate in this group is $3.92 \%$, as shown in Graph 3. It should be $<3 \%$ as a constant. In our study in 2014, it is slightly higher while it was $12.99 \%$ in 2013. This three-fold high in the previous year may be attributed to increased number of high-risk cases in the group.

Groups I and III, being the spontaneous labor group, are half of the total laboring women, implying more number of women going for spontaneous labor and less number of induction and prelabor. Ideally, it should have included one-third of the total number of women. 
Group IV: The CS rate in this group is $5.56 \%$ in 2014 and $5.88 \%$ in 2013 . The rate in this group should be 5 to $8 \%$ and is relatively consistent. It is all within normal range. Group $V$ : It is a heterogeneous group which contributes the maximum to CS rate. In our study, the relative size of this group is $11.47 \%$ in 2014 while it is $8.7 \%$ in 2013 , which shows that there had been high CS rates in previous years mainly from groups I and II. This group contributed highest to CS in our study at $11.12 \%$.

We subclassified these women: There were 1,412 women who had a history of previous 1 cesarean section, 71 women had a history of previous 2 cesarean sections, and 1 woman had a history of previous 3 cesarean sections. There were three cases of ruptured uterus in this group that underwent peripartum hysterectomy as a consequence of scar rupture.

In groups VI to $\mathrm{X}$, the CS rate is high but these contributed less to the overall CS rate.

Group VI: The CS rate in this group is $98.16 \%$; its overall contribution is less, accounting to $1.65 \%$ in 2014. In 2013, the CS rate is $72.4 \%$ and its overall contribution is $1.05 \%$. Most nulliparous breeches are now delivered by CS.

Group VII: The relative size of this group in 2014 is $1.32 \%$ and the overall contribution to CS is $0.69 \%$ while in 2013 , it is 1.17 and $0.59 \%$ respectively.

The CS rates in these two groups are now close to $100 \%$, but because the groups are not bigger than 3 to $4 \%$, together they will never make a large contribution to the overall CS rate.

Group VIII: The size of the group will vary, mainly according to the different types of infertility treatment. In our study, the relative size is $0.85 \%$ and its contribution to the overall CS rate is $0.44 \%$ in 2014 . The relative size is $0.53 \%$ and the overall CS rate is $0.12 \%$ in 2013 . This group has a significantly high perinatal mortality rate.

Group IX: The relative size of this group should be 0.4 to $0.8 \%$. In our study, it is $0.53 \%$ in 2014 and is $0.22 \%$ in 2013 . The CS rate in this group is $100 \%$ in both the years which is helpful in assessing the quality of data collection which is very good in our study.

Group X: Usually the CS rate in this group is $<10 \%$. In our study, it is $11.13 \%$ which is slightly higher in 2014 and is $9.19 \%$ which is appropriate in 2013. The average size of this group is 5\% but in our study it is $8.05 \%$ in 2014 and is $3.58 \%$ in 2013 .

It signifies the incidence of fetal and maternal medical conditions, such as intrauterine growth restriction and preeclampsia. This is one of the reasons for high CS rate in a tertiary hospital. The CS is mainly seen in late preterm between 36 and 37 weeks of gestation.

\section{SUMMARY}

- Relative size of group IX is $0.53 \%$ and CS rate is $100 \%$, suggesting good data collection.
- Overall CS rate is $29.33 \%$, which is higher than $\mathrm{WHO}$ standard and even higher than the previous year which was $25.83 \%$.

- The CS rate in group I is $6.13 \%$ and in the previous year it was $12.95 \%$, so it is reduced by half by careful monitoring.

- The CS rate in group II remained high at $20.52 \%$ than the previous $14.73 \%$.

- Relative size of group I+ II is $47.99 \%$, more than expected $42 \%$.

- The CS rate in group III became optimum at 3.92\% which was three times higher in the previous year at $12.99 \%$.

- The CS rate in group IV is also reduced in 2014, which is $23.36 \%$ as compared to $38.68 \%$ of the previous year.

- Group V had 96.9\% CS rate.

- Relative size of groups VI and VII is less than $4 \%$.

- The CS rate in group $X$ is $11.13 \%$, indicating high preterm cesarean sections.

\section{CONCLUSION}

There are many reasons for CS delivery for pregnant woman. It is the sole decision of the obstetrician to analyze for CS if it is appropriate or not as a concern for the betterment of the mother and baby.

We can classify the CS according to women's group, which is inclusive totally and mutually exclusive. Robson's classification is easy in collecting information about CS rate. This classification system can provide critical assessment of care at delivery and can be used to change practice if used on a continuous basis. However, this classification will not be able to analyze indication for CS.

\section{REFERENCES}

1. WHO. Appropriate technology for birth. Lancet 1985;2: 436-437.

2. Villar J, Carroli G, Zavaleta N, Donner A, Wojdyla D, Faundes A, Velazco A, Bataglia V, Langer A, Narváez A, et al. Maternal and neonatal individual risks and benefits associated with caesarean delivery: Multicentre prospective study. BMJ 2007 Nov;335(7628):1025. doi: 10.1136/bmj.39363.706956.55.

3. Villar J, Valladares E, Wojdyla D, Zavaleta N, Carroli G, Velazco A, Shah A, Campodónico L, Bataglia V, Faundes A, et al. Caesarean delivery rates and pregnancy outcomes: The 2005 WHO global survey on maternal and perinatal health in Latin America. Lancet 2006 Jun;367(9525):1819-1829.

4. Lumbiganon P, Laopaiboon M, Gulmezoglu AM, Souza JP, Taneepanichskul S, Ruyan P, Attygalle DE, Shrestha N, Mori R, Nguyen D, et al. Method of delivery and pregnancy outcomes in Asia: The WHO global survey on maternal and perinatal health 2007-08. Lancet 2010;375:490-499.

5. Betran AP, Merialdi M, Lauer JA, Bing-shun W, Thomas J, Van Look P, Wagner M. Rates of caesarean section: analysis 
of global, regional and national estimates. Paediatr Perinat Epidemiol 2007;21:98-113.

6. Gibbons L, Belizan JM, Lauer JA, Betran AP, Merialdi M, Althabe F. The global numbers and costs of additionally needed and unnecessary caesarean sections performed per year: Overuse as a barrier to universal coverage. World Health Report. Geneva, Switzerland: World Health Organization; 2010.

7. Robson MS. Classification of caesarean sections. Fetal Matern Med Rev 2001 Feb;12(1):23-39.
8. Torloni MR, Betran AP, Souza JP, Widmer M, Allen T, Gulmezoglu M, Merialdi M. Classifications for cesarean section: A systematic review. PLoS One 2011;6(1):e14566. doi: 10.1371/journal.pone.0014566

9. Prameela RC, Farha A, Prajwal S. Analysis of caesarean section rate in a tertiary hospital - according to Robson's 10 group classification system (TGCS). IOSR-JDMS 2015 Feb;14(2): 46-49.

10. Robson M. Method of achieving and maintaining appropriate CS rate. Best Pract Res Clin Obstet Gynaecol 2013;2.. 